\title{
Fossil and recent soil formation in Late Pleistocene loess deposits in the southern part of the Netherlands
}

\author{
S. Slager, A. G. Jongmans, R. Miedema and L. J. Pons \\ Department for Soil Science and Geology, Agricultural University, P.O. Box 37, \\ Wageningen, the Netherlands
}

Accepted: 15 March 1978

Key words: paleo-ecopedology, loess stratigraphy, soil micromorphology.

\section{Summary,}

In the younger, Weichselian (Würm, Wisconsin) loess deposits in the south of the Netherlands a horizon is found with fossil pedotubules (filled animal burrows). These pedotubules, $3 \mathrm{~mm}( \pm 1 \mathrm{~mm})$ in diameter, not branched, without preferent orientation, have their largest abundance in the zone extending from about $30 \mathrm{~cm}$ above the decalcification boundary (situated $2-3 \mathrm{~m}$ below the soil surface) to some decimeters below it. In the B3t horizon of the overlying Hapludalf they rarely occur. Their lower extension boundary occurs some $2 \mathrm{~m}$ below the decalcification boundary. It will be shown that these tubules result from fossil animal activity followed by decalcification mainly related to a Bølling soil surface.

In the post-Bølling period a loess layer would have been deposited of some 2 $\mathrm{m}$ thickness, the lower part of which displays a lamellae spot zone. Micromorphological evidence shows that the lamellae spot zone originally has been present to the actual soil surface. Consequently a geogenic origin of the lamellae spot zone rather than a pedogenic origin seems likely. Soil formation subsequently intensified the textural differences.

The hypothesis is developed that the post-Bølling loess was free of calcium carbonate at the beginning of the Holocene. Either it was deposited noncalcareously or decalcified synsedimentarily.

It is concluded that in Western European loess deposits due to Pleistocene predisposition soils reached the stage of maturity earlier in the Holocene than was assumed hitherto.

\section{Introduction}

According to several authors loess sedimentation during the Weichselian (Würm, Wisconsin) period did not proceed later than about 12000 years ago (Bølling Interstadial) in Western Europe (e.g. van Marel and van den Broek, 1962; Anon., 
1965; Paas, 1969). Zagwijn \& Paepe (1968) left the possibility open for a postBølling loess sedimentation. In the German Federal Republic positive evidence of Late-Glacial loess sedimentation was presented by Schönhals (1960) and Frechen \& Rosauer (1959). It is well-known that certain coversands have been deposited in the Late-Glacial (Young Coversands 1 and 2) (van der Hammen et al., 1967). One might ask whether Late-Glacial loess deposits do not occur in the Netherlands or that they have not yet been recognized as such.

Another intriguing question is that of the decalcification. In loess profiles in the Netherlands (and neighbouring areas in Belgium and Western Germany) which were not eroded recently, the upper 2 to 3 metres of loess are free of calcium carbonate. With few exceptions (Lieberoth, 1959, 1962, 1963) this phenomenon is ascribed to Holocene decalcification (van Marel \& van den Broek, 1962; Dudal, 1953; Meyer et al., 1962). The relatively small amounts of secondary lime which are found below the decalcification boundary should explain the loss of some 10-15\% calcium carbonate in the upper few meters (Mücher, 1973). The occurrence of chernozem-like soils in Western Europe (Kopp, 1965; Dudal, 1953) in the Early Holocene is obviously based on the assumption that the loess was calcareous up to the soil surface then.

Macro- and micromorphological observations on a number of profiles developed in young Weichsel loess in the southern part of the Netherlands, which will be reported in this paper, point to post-Bølling loess sedimentation and soils which were free of lime to great depth at the beginning of the Holocene.

\section{Observation}

\section{The Nuth profile (Fig. 1)}

\section{Macromorphology}

Topographical Map of the Netherlands (1968), sheet to 60C, coordinates N 326. 570 - - E. 188. 670; Typic Hapludalf (Soil Conservation Service, 1975); formerly arable land, now excavation; Würm $\gamma$ loess over Würm $\beta$ (Lieberoth, 1962, 1963) loess over Pleistocene river deposits; flat; plateau, near edge; $117 \mathrm{~m}$ above mean sea level; well-drained.

Soil horizons (abridged; moist Munsell colours):

Ap $\quad 0-25 \mathrm{~cm}, 10$ YR $5 / 4$; silt loam; weak platy, abrupt and smooth on:

Bit 25-45 cm, 10YR5/6; silt loam; weak (sub)angular blocky; gradual and smooth on:

B2t $\quad 42-85 \mathrm{~cm} ; 7.5 Y R 5 / 6$; silt loam; moderate prismatic; distinct, irregular, very pale brown silty spots, sometimes tending to horizontal elongation; diffuse and smooth on:

B31t $85-130 \mathrm{~cm} ; 7.5 Y R 6 / 6$; silt loam; weak (sub)angular blocky tending to sponge; distinct, very pale brown silt streaks, horizontally elongated: diffuse and smooth on:

B32t 130-190 cm; silt loam; sponge, with increasing depth changing into a lamellar stratification consisting of discontinuous lamellae of fine textured 


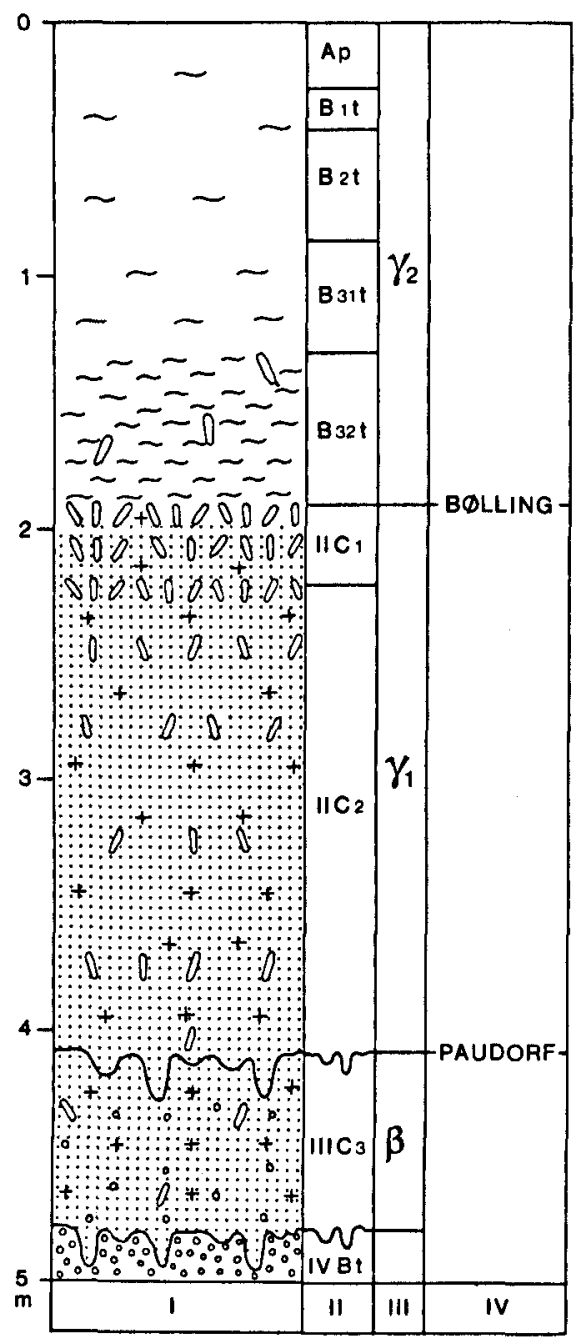

Fig. 1. Schematic reproduction of the Nuth profile.

Column I. The parent materials $(0-408 \mathrm{~cm}$ : loess; $408-478 \mathrm{~cm}$ : loess with admixture of fluviatile gravel; + $478 \mathrm{~cm}$ : fluviatile terrace material), the position of the lamellae spot zone, the distribution of primary and secondary lime, and the distribution of the fossil pedotubules.

Colomn II. The horizon designation according to Anon. (1975).

Colomn III. The stratigraphical designation of the loess layers according to Lieberoth (1962, 1963).

Column IV. The position of the Paudorf soil surface, as concluded from Kuyl (1975) and Kuyl \& Bisschops (1969). The position of the Belling soil surface as explained in the text.

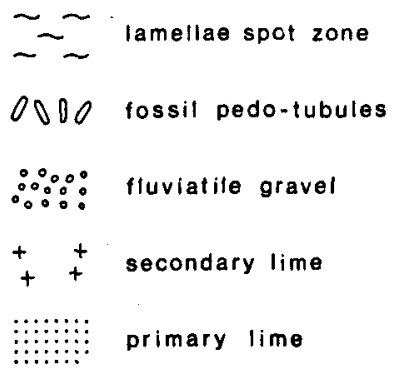

yellow (7.5YR6/6) material and silty very pale brown (10YR8/3) material some pedotubules as described for the IIC1-horizon; gradual and smooth on:

IIC1 190-223 cm; 10YR6/6, silt loam; sponge; common pedotubules in all directions, diameter $3 \mathrm{~mm}$ ( $\pm 1 \mathrm{~mm}$ ); abrupt and smooth on:

IIC2 223-408 cm; $2.5 \mathrm{Y} 7 / 6$; silt loam; sponge; pedotubules as in the IIC1, decreasing in abundance with depth; few, locally common, fine, distinct channelneocalcitans; strong reaction on $2 \mathrm{~N} \mathrm{HCl}$; clear and wavy, locally tongued (cryoturbate) on:

IIIC3 $408-478 \mathrm{~cm} ; 10$ YR6/6, silt loam with some gravel; sponge; few, fine, distinct, channelneocalcitans and calcite nodules strong reaction on $2 \mathrm{~N}$ $\mathrm{HCl}$; clear and wavy, locally tongued on:

IVBt $+478 \mathrm{~cm} ; 2.5$ YR5/6, gravelly loamy sand. 
Micromorphology (Unless stated otherwise, the terminology of Brewer (1964) is used.

The groundmass consists between 0 and $240 \mathrm{~cm}$ of skeleton grains and plasma. The skeleton grains in the upper $223 \mathrm{~cm}$ comprise quartz, mica, feldspar, glauconite and heavy minerals; between 223 and $420 \mathrm{~cm}$, moreover, many calcitic skeleton grains were found. The skeleton grains between 0 and $130 \mathrm{~cm}$ occur in a random distribution pattern which changes with increasing depth into a clustered distribution pattern. Between 130 and $190 \mathrm{~cm}$ they occur mainly in a banded distribution pattern. The skeleton grains between 190 and $420 \mathrm{~cm}$ occur mainly in a random distribution pattern.

The plasma from 0 to $223 \mathrm{~cm}$ consists of clay minerals and ferric compounds with a silasepic plasmic fabric. Below $223 \mathrm{~cm}$ it consists of clay minerals and calcium carbonate with a crystic plasmic fabric. Between 0 and $130 \mathrm{~cm}$ the plasma occurs in a random to clustered distribution pattern, between 130 and $190 \mathrm{~cm}$ mainly in a clustered and banded distribution pattern. Below $190 \mathrm{~cm}$ a small part of the plasma is concentrated in thin (up to $20 \mu \mathrm{m}$ ), short (up to some millimetres) bands more or less parallel to the soil surface. The remainder of the plasma occurs random.

Apart from discontinuous voids a large number of channels was found. They can be separated into two groups:

- rather wide $(2-6 \mathrm{~mm})$ channels, which were never found to be branched; their abundance decreases between 0 and $130 \mathrm{~cm}$;

- finer channels $(50 \mu \mathrm{m}-2 \mathrm{~mm}$ ) which are either branched or not branched; these fine channels occur at all depths between 0 and $420 \mathrm{~cm}$.

The following special features were found.

- In the lowest part of the profile, deeper than $408 \mathrm{~cm}$, pedorelicts were encountered. They consist of large skeleton grains, up to $1 \mathrm{~mm}$, enveloped by ferri argillans with a continuous orientation.

- Ferric nodules have been found throughout the profile. Some of them are diffusely bounded, others have sharp boundaries. They range in size from $50 \mu \mathrm{m}$ to some millimetres. Their occurrence is random, their abundance small.

- Secondary lime was found between 223 and $408 \mathrm{~cm}$. The amount decreases with depth. The amount is small. It occurs as channelneocalcitans and calcitic nodules, which both are randomly distributed.

- Ferri argillans and related papules occur between 20 and $230 \mathrm{~cm}$ below the soil surface. The maximum amount was found between 80 and $120 \mathrm{~cm}$ (B31t). From thereon they decrease in abundance with depth. Generally the observed ferri argillans and derived papules consist of strongly oriented clay. Between 130 and 190 $\mathrm{cm}$ the ferri argillans are preferently but not exclusively found in the bands and spots, which are relatively rich in plasma.

- Matri-ferri argillans (van Schuylenborgh et al., 1970) and related papules were found between 20 and $250 \mathrm{~cm}$, below the soil surface. The maximum amount occurs between 170 and $190 \mathrm{~cm}(\mathrm{~B} 32 \mathrm{t})$. They mainly occur in relatively large channels.

- Two types of pedotubules were observed. (1) Aggrotubules with a diameter of

Neth. J. agric. Sci. 26 (1978) 
3-6 $\mathrm{mm}$, which mainly occur between 0 and $130 \mathrm{~cm}$. Some of them were found up to $190 \mathrm{~cm}$. Deeper they were not found. They generally contain ferri argillaceous papules, sometimes ferri argillans in situ. They are almost exclusively vertically oriented. (2) iso-striotubules with diameters which are mostly $3 \mathrm{~mm}$, seldom $1 \mathrm{~mm}$ larger or smaller. They are mainly concentrated between 190 and $250 \mathrm{~cm}$. Very few were found shallower, between 190 and $150 \mathrm{~cm}$; some were found deeper, up to $408 \mathrm{~cm}$. None of them was found to contain ferri argillaceous papules or ferri argillans in situ. They do not shows a preferent orientation. The striae in the tubules often occur at angles of more than $45^{\circ}$ in relation to the actual soil surface. Above the decalcification boundary they were never found to contain calcium carbonate; below this boundary they contain the same amount of primary calcium carbonate as the adjoining matrix.

\section{Other profiles}

In another ten profiles which are considered to have developed in the Late-Weichselian loess in the Netherlands the above sequence of recent and fossil soil horizons was fuund. This sequence includes in uneroded profiles in plateau position: A1, A2, B2t, B3t and C1 (the B3t with a lamellae spot zone; Lieberoth, 1959). Between two and three metres below the soil surface follows a calcareous C2 (IIC2). Some decimetres above and below the decalcification boundary the described typical iso-striotubules of $3 \mathrm{~mm}$ diameter were found. Some two metres below the decalcification boundary a distinct cryoturbate fossil A1 horizon occurs. In one case, profile Sittard, this horizon was dated by means of C14 (Kuyl \& Bisschops, 1969; Kuyl, 1975; \pm 28000 years old = Denekamp Interstadial = Paudorf Instadial; cf. Zagwijn \& Paepe, 1968).

In the neighbouring countries, this cryoturbate fossil A1 horizon, which has a guide function, was noticed and named: in Belgium as the Kesselt soil (Gullentops, 1957; Zagwijn \& Paepe, 1968), in Germany as the Gleina soil (Lieberoth, 1962). The pedotubule horizon has not yet been mentioned in literature as far as known to us. The lamellae spot zone (Lieberoth, 1959, 1962, 1963) is found in many places (Fink, 1969; Paas, 1969; Altemüller \& Bailly, 1976). It was not mentioned in Dutch publications up till now, although a picture of it has been published (de Bakker \& Schelling, 1966, Fig. 34). It is clear that the vertical sequence of phenomena in the Nuth profile is not restricted to this profile. Consequently the mode of formation of this vertical sequence has a wider validity than for the Dutch loess area alone.

\section{Interpretation and discussion}

A number of questions will be discussed in this section.

- the origin of the iso-striotubules, as well as the environmental conditions prevailing during their formation. It will be shown that the iso-striotubules result from fossil animal activity followed by decalcification mainly related to a Bølling soil surface situated immediately below the lamellae spot zone.

- the origin of the lamellae spot zone and the conditions under which it was 
formed. The conclusion will be drawn that the lamellae spot zone was formed in a post-Bølling loess deposit which either was sedimented non-calcareously or decalcified synsedimentary under periglacial conditions.

- the consequences for the age of the soils developed in loess deposits similar to the described one in Western Europe. It seems that in these deposits due to a Pleistocene predisposition soils reached maturity rather early in the Holocene.

\section{Soil formation in the Bolling Interstadial}

The iso-striotubules which occur from some decimetres above the decalcification boundary to some metres below it, are ascribed to fossil animal activity. Thus are excluded recent zoogenic activity and fossil as well as recent phytogenic activity as possible origin.

The morphology of the iso-striotubules strongly points to animal activity. They were never found to be branched; their diameter is always $3 \mathrm{~mm}$ within narrow limits; they have no preferent orientation (horizontal ones occur as frequently as vertical and oblique ones); the striae in the tubules often occur at angles of more than $45^{\circ}$ in relation to the soil surface, thus excluding a passive fill-in of the former channels.

The iso-striotubules are rather easily recognized from more recent animal burrows, which are observed as large channels and as aggrotubules with or without ferri argillaceous papules or ferri argillans in situ. The amount of these more recent animal burrows decreases with depth and they are rarely found deeper than $1.5 \mathrm{~m}$ below the soil surface.

The observed phytogenic channels, either recent of fossil are smaller $(50 \mu \mathrm{m}$ $2 \mathrm{~mm}$ ), often branched and run vertical or oblique, rarely horizontal. They do not show any systematic change in abundance with depth.

As for the fossil character of the iso-striotubules, their maximum abundance is found between the lower end of the lamellae spot zone and the decalcification boundary; very few of these tubules are found in the lamellae spot zone; none are observed in the upper $1.5 \mathrm{~m}$ of the soil; they do not change with shallower depth into open channels or any type of tubules; they must have been formed before the decalcification boundary since they do not contain calcium carbonate above the decalcification boundary and below it they contain the same amount of calcium carbonate as the adjoining matrix.

It seems worth-while to try and indicate the period of formation of these fossil animal burrows and the conditions under which they have been formed. The animals, the nature of which is still unknown, have not been digging in large numbers from a soil surface situated above the lamellae spot zone, since very few iso-striotubules are found there and the lamination is still largely undisturbed. Thus the activity of the indicated animals should be placed in the period just before the formation of the lamellae spot zone, i.e. just before the deposition of the sediment which displays a lamellar structure. The latter sediment designated by Lieberoth (1963) as Würm $\gamma 2$ loess, would have been deposited in his view immediately after the first interstadial following the Paudorf i.e. immediately after the Bølling (12 $400-12000$ years ago). 
Although the bulk of the described fossil animal burrows may be related to a Bølling soil surface, some of them seem to be older and some younger. As for the older ones, it is improbable that the animals have been digging more than $2 \mathrm{~m}$ deep from a Bølling soil surface. We rather think that during the cold period between Paudorf and Bølling the animal activity continued, although at a low level, from a soil surface which gradually changed in position due to loess sedimentation. The data on the phytogenic channels point into the same direction. This

point of view, however, would imply that on the investigated site we are dealing with some vegetation and that therefore the arctic desert without any vegetation (van der Hammen et al., 1967) has to be excluded. The very few fossil animal burrows which occur above the Bølling soil surface may originate either from the Bølling-Allerød stadial or from the Allerød interstadial. The depth of the Allerød soil surface can not be indicated, but must be situated somewhere within the pedosphere of the overlying Hapludalf.

Apart from animal activity decalcification took place during the Bølling interstadial. The pre-Bølling loess has been decalcified for some decimetres following the animal activity in the Bølling period. The corresponding amount of secondary lime is found below the decalcification boundary.

The lamellae spot zone and the absence of calcium carbonate in the post-Bolling loess

From the data of Lieberoth (1963) we concluded that the loess layer in which the lamellae spot zone occurs is a post-Bølling loes. Allerød soils and post-Allerød loess deposits have been described by Schönhals $(1957,1960)$ and by Frechen \& Rosauer (1959) for the German Federal Republic. Loess deposits originating from the Bølling-Allerød stadial have not yet been described as far as known to us.

Lieberoth (1963) only described the lamellae spot zone for the lower part of the post-Bølling loess. Our macro- and micromorphological observations reveal that the lamellae spot zone originally has been present up to the actual soil surface (clustered distribution pattern of skeleton grains near the soil surface which changes gradually with depth into a banded distribution pattern). Near the soil surface the lamellation was largely destroyed by bioturbation. The mode of formation of the lamellae spot zone, sensu stricto, thus holds for the post-Bølling loess layer as a whole and will be discussed hereafter. The mode of formation of the lamellae spot zone has given rise to much discussion in literature. Lieberoth (1959, 1963) ascribed the formation to a synsedimentary partial texture differentiation with transport of fine components over short distances. Lieberoth hinted to an alternation of freezing and thawing without disclosing details. In a more recent paper Federova \& Yarilova (1972) described in detail recent soil formation in prolonged seasonally frozen taiga soils in Western Siberia. Their micromorphological description of plasma and skeleton grain distribution patterns very much resembles ours of the lamellae spot zone.

Quite another view is expressed by Schönhals et al (1964) and by Altemüller \& Bailly (1976). In their opinion the alteration of silty and of fine-textured lamellae is of pedogenic origin: mini-A2 and mini-B2t horizons. Textural differentiation 
would then have occurred only vertically.

Paas (1969) stated that both processes have been active: a primary geogenic textural differentiation which was intensified later on by pedogenesis. We share this opinion with Paas. It can not be denied that the fine-textured lamellae (which contain more unoriented clay than the silty lamellae) have more illuviated clay than the silty ones. The latter, however, do contain too much illuviated fine clay to be neglected. In a number of cases, moreover, we could observe that the maximum size of the skeleton grains in the silty lamellae was larger than that of the skeleton grains in the underlying finer-textured lamellae.

Lieberoth $(1959,1963)$ stresses the fact that the said partial texture differentiation can only develop in the absence of calcium carbonate. We are munch inclined to follow his point of view. In the material which originally contained calcium carbonate (and still does), i.e. below the decalcification boundary, a partial textural differentiation took place, but to a very small extent only. The best explanation available is that a significant textural differentiation is only possible when the calcium carbonate does not any more hold the clay flocculated.

The question arises how the post-Bølling loess became non-calcareous. Either it was free of lime when deposited or it was decalcified synsedimentary. Lieberoth (1959) in the beginning did not choose among the two possibilities. In later publications $(1962,1963)$ he adopted the first view. Current theories (see Mücher, 1973) state that the loess was originally calcareous up to the actual soil surface. It would have contained at least $10 \%$ calcium carbonate. The amount of secondary lime we found does not suffice, however, to explain the decalcification of a post-Bølling loess layer of about to metres with $10 \%$ calcium carbonate. Such a decalcification is only acceptable if the loess was decalcified synsedimentary with subsequent removal of the calcium carbonate from the area over a frozen subsoil.

In conclusion it seems justified to assume, that the post-Bølling loess was free of calcium carbonate at the beginning of the Holocene. If the post-Belling loess contained calcium carbonate at all when deposited, it must have been decalcified synsedimentary.

\section{Pleistocene predisposition and Holocene soil development}

In literature quite another view is presented: the post-Bølling loess should have been calcereous and should have been decalcified from the actual soil surface (Dudal, 1953; Kopp, 1965; van Marel \& van den Broek, 1962; Meyer et al., 1962; Jamagne, 1972; Mücher, 1973). The models (Dudal, 1953; Kopp, 1965; Jamagne, 1972) which are based on the assumption that in many places in Western Europe soil formation started at the beginning of the Holocene in completely calcareous loess deposits, in our opinion, now need correction. Kop (1965), for instance, described the occurrence in West Germany of Chernozem relics. They would be remnants of a, possibly widespread, early Holocene, occurrence of Chernozems on the loess. The present Alfisols in that theory would be dregraded Chernozems. In our opinion, the occurrence of Chernozem relics in Western Europe is not as general as Kopp suggested. The Chernozems could only develop where the post- 
Bølling loess was absent (either not deposited or eroded) at the beginning of the Holocene.

The idea of a Pleistocene predisposition is not new. As early as 1960 Hoeksema \& Edelman already indicated the possibilities of Late Pleistocene decalcification, immediately followed by a textural-B formation. According to Slager \& van de Wetering (1977) clay illuviation in loess soils in Western Europe is rather an early Holocene than a recent process. A prerequisite for clay illuviation is the absence of calcium carbonate in at least the topsoil. The explanation of the absence of lime at the beginning of the Holocene up till now formed the missing link. We must conclude that in the investigated site, and judging from literature in many loess soils in Western Europe, pedogenesis earlier reached a rather advanced stage than was accepted hitherto.

\section{Acknowledgments}

The authors are indebted to many colleagues for stimulating discussions on the subject displayed in this paper. In particular they want to extend their sincere gratitude to Prof. Dr J. D. de Jong, Wageningen and Mr H. J. Mücher, Amsterdam for their comments on the manuscript.

\section{References}

Altemüller, H. J. \& F. Baily, 1976. Mikromorphologische Untersuchungen an einer nordwestdeutsohen Parabraunerde. Geoderma 16 (4) 327-345.

Anonymous, 1965. De bodem van Nederland. Stichting voor Bodemkartering, Wageningen, $292 \mathrm{pp}$.

Anonymous, 1975. Soil taxonomy. USDA Handbook No 436. Soil Conservation Service.

Bakker, H. de \& J. Schelling, 1966. Systeem voor bodemclassificatie van Nederland, Pudoc, Wageningen, 217 pp.

Brewer, R., 1964. Fabric and mineral analysis of soils. Wiley, New York-London-Sidney, $470 \mathrm{pp}$.

Dudal, R. 1953. Etude morphologique et genétique d'une séquence de sols sur limon loessique. Extr. Agric. 1: 119-163.

Federova, N. N. \& E. A. Yarilova, 1972. Morphology and genesis of prolonged seasonally frozen soils in western Siberia. Geoderma 7: 1-13.

Fink, J., 1969. Les progrès de 1 étude des loess en Europe. In: La stratigraphie des loess d'Europe. Bull. Ass. franc. Etude Quarternaire. (Suppl.) 1-12.

Frechen, J. \& E. Rosauer, 1959. Aufbau und Gliederung des Würm-Loess-Profils van Kärlich in Neuwieder Becken. Fortschr. Geol. Rheinl. Westf. 4: 267-282.

Gullentops, F., 1957. Stratigraphe du Pleistocène supérieur en Belgique. Geol. Mijnb. 19: 305-306.

Hammen, T. van der, G. C. Maarleveld, J. C. Vogel \& W. H. Zagwijn, 1967. Stratigraphy, climatic succession and radiocarbon dating of the Last Glacial in the Netherlands. Geol. Mijnb. 46: 79-95.

Hoeksema, K. J. \& C. H. Edelman, 1960. The role of biological homogenization in the formation of Gray-Brown Podzalic Soils. Trans. 7th Congr. Int. Soc. Soil Sci. 4: 402-405.

Jamagne, M., 1972. Caractères micromorphologiques des sols développés sur formations limoneuses. Bull. Ass. franç. Etude Sol 1: 9-32.

Kopp, E., 1965. Uber Vorkommen degradierter Steppenböden in den Lössgebieten des Niederrheins und Westfalen und ihre Bedeutung für die Paläobodenkunde und Bodengenese. Eis- 
zeitalter Gegenwart 16: 97-112.

Kuyl, O. S., 1975. Löss. Grondboor Hamer 29: 2-13.

Kuyl, O. S. \& J. H. Bisschops, 1969. Le loess aux Pays-Bas. In: La stratigraphie des loess d'Europe. Ass. franç. Etude Quarternaire (Suppl.) 101-104.

Lieberoth, I., 1959. Beobachtungen im nordsächsischen Lössgebiet. Z. PflErnähr. Düngung Bodenk. 86: 141-155.

Lieberoth, I., 1962. Die jungpleistozänen Lösse Sachsens im Vergleich zu denen anderer Gebiete. Petermanns geogr. Mitt. 106: 188-197.

Lieberoth, I., 1963. Löss Sedimentation und Bodenbildung während des Pleistozäns in Sachsen. Geologie 12: 149-187.

Marel, H. W. van \& J. M. M. van den Broek, 1962. Calcium-Magnesium and PotassiumMagnesium relations in loess soils of Limburg. Boor Spade (Neth. Soil Survey) 12: 103-111.

Meyer, B., E. Kalk \& H. Fölster, 1962. Parabraunderden aus primär carbonathaltigem Würmlöss in Niedersachsen. I. Z. PflErnähr. Düngung Bodenk. 99: pp 37-54.

Mücher, H. J., 1973. Enkele aspekten van de loess en zijn noordelijke begrenzing in het bijzonder in Belgisch en Nederlands Limburg en in het daaraangrenzende gebied in Duitsland. KNAG geog. Tijdschr. 7: 259-276.

Paas, W., 1969. Gliederung und Alterstellung der Lösse am Niederrhein. Fortschr. Geol. Reinl. Westf. 16: 185-196.

Schönhals, E., 1957. Spätglaziale äolische Ablagerungen in einigen Mittelgebirgen Hessens. Eiszeitalter Gegenwart 8: 5-17.

Schönhals, E., 1S60. Spät- und Nacheiszeitliche Entwicklungsstadien von Böden aus Äolischen Sedimenten in West Deutschland. Trans. 7th int. Congr. Soil Sci. 4: 283-290.

Schönhals, E., H. Rohdenburg \& A. Semmel, 1964. Ergebnisse neuerer Untersuchungen zur Würmlöss-Gliederung in Hessen. Eiszeitalter Gegenwart 15: 199-206.

Schuylenborgh, J. van, S. Slager \& A. G. Jongmans (1970). On soil genesis in temperature humid climate. VIII. The formation of a 'Udalfic' Eutrochrept. Neth. J. agric. Sci. 18: 207-214.

Slager, S. \& H. T. J. van de Wetering, 1977. Soil formation in archaeological pits and adjacent loess soils in southern Germany. J. archaeol. Sci. 4: 259-267.

Zagwijn, W. \& R. Paepe, 1968. Die Stratigraphie der weichselzeitlichen Ablagerungen der Niederlande und Belgiens. Eiszeitalter Gegenwart 19: 129-146. 